\title{
PERILAKU KEPEMIMPINAN KEPALA SEKOLAH DI SMA NEGERI 1 LEMITO
}

\author{
${ }^{1}$ Irwilda H Bay ${ }^{*}{ }^{2}$ Sarson W. Dj. Pomalato \\ ${ }^{1,2}$ Universitas Negeri Gorontalo \\ ${ }^{*}$ irwildabay77@gmail.com, ${ }^{2}$ sarson@ ung.ac.id
}

\begin{abstract}
ABSTRAK
Penelitian ini bertujuan untuk menggambarkan bagaimana perilaku kepemimpinan kepala sekolah dalam mengarahkan dan mengkoordinasikan untuk mewujudkan visi dan misi di SMA Negeri 1 Lemito. Hasil penelitian menunjukkan bahwa kepemimpinan kepala sekolah SMA Negeri 1 Lemito telah menerapkan beberapa perilaku kepemimpinan yang efektif dan efisien tepadu dan terintegrasi dalam tugas warga sekolah terutama dalam kebijakan perilaku kepala sekolah. Perilaku yang dikembangkan adalah suportif, leadership, direktif leadership, dan partisipatif. Pengelolaan perilaku kepempimpian di sekolah akan membentuk lingkungan sekolah lebih berkualitas dan profesional sebagaimana visi SMA Negeri 1 Lemito, terutama untuk menjaga keharmonisan warga sekolah. Perilaku kepemimpinan ternyata masih dipengaruhi oleh proses pendelegasian tugas, transparansi, dan akuntabilitas yang kurang dan budaya kerja baru yang sulit diterima oleh warga sekolah. Kebijakan yang telah dijabarkan oleh kepala sekolah melalui visi misi dapat menggambarkan kebarhasilan seorang pemimpin dalam menekan konflik internal sekolah di samping penentuan proses perilaku kepemimpinan dipengaruhi oleh kompetensi-kompetensi, kepribadian seorang pemimpin. Dengan demikian, kompetensi dan kepribadian yang dimiliki seorang pemimpin dapat mempengaruhi kinerja kepemimpinan. Dalam perilaku pemimpin yang mendelegasikan tugasnya masih dipengaruhi oleh keraguan pada tingkat kepercayaan warga sekolah, kemampuan dan skill, serta masih masih rendahnya prestasi kerja warga sekolah. Untuk itu, kepala sekolah melalukan perubahan dalam perilaku terutama dari segi supportive leadership dan achievement-oriented leadership, sehingga dapat menekan konflik internal di sekolah, kepala sekolah meningkatkan tanggung jawab warga sekolah pada tugas yang telah diberikan.
\end{abstract}

Kata kunci: Perilaku, Kepemimpinan, Kepala Sekolah

\begin{abstract}
This study aims to describe how the principal's leadership behavior in directing and coordinating to realize the vision and mission of SMA Negeri 1 Lemito. The results showed that the leadership of the principal of SMA Negeri 1 Lemito had implemented several leadership behaviors that were effective and efficient, integrated and integrated into the duties of the school community, especially in the behavior policy of the principal. The behaviors developed are supportive, leadership, directive leadership, and participatory. Management of leadership behavior in schools will form a more qualified and professional school environment as the vision of SMA Negeri 1 Lemito, especially to maintain the harmony of the school community. Leadership behavior is still influenced by the process of task delegation, lack of transparency and accountability and a new work culture that is difficult for school members to accept. The policies that have been described by the principal through the vision and mission can describe the success of a leader in suppressing school internal conflicts in addition to determining the process of leadership behavior influenced by the competencies, personality of a leader. Thus, the competence and personality of a leader can affect leadership performance. The behavior of leaders who delegate their duties is still influenced by doubts about the level of trust of school members, abilities, and skills, as well as the low work performance of school residents. For this reason, school principals make changes in behavior, especially in terms of supportive leadership and achievement-oriented leadership, so that they can suppress internal conflicts in schools, principals increase the responsibility of school residents on the tasks that have been given.
\end{abstract}

Keywords: Behavior, Leadership, Principal 


\section{PENDAHULUAN}

Kata kepemimpinan bukanlah hal yang baru bagi kehidupan kita. Kata kepemimpinan sudah lama ada sesuai dengan perkembangan zaman. Dalam kehidupannya manusia tidak terlepas dari apa yang namanya kempemimpinan. Kepemimpinan sudah merupakan kebutuhan manusia dalam kehidupan bermasyarakat, berbangsa dan bernegara.

Di dalam menjalankan suatu aktivitas untuk memenuhi kebutuhan dan kelangsungan hidup maka diperlukan suatu organisasi dan koordinasi. Untuk menorganisasikan dan menkoordinasikan segala sesuatu menjadi berarti dengan adanya pimpinan. Keberadaan pimpinan diharapkan dapat meningkatkan perubahan dalam kehidupan bernegara. Sebagaimana pendapat (Rivai, 2004:1-2) setidaknya ada empat alasan mengapa pimpinan diperlukan, yaitu: (a) banyak orang yang memerlukan figur pemimpin, (b) dalam beberapa situasi, seorang pemimpin perlu tampil mewakili kelompoknya, (c) sebagai tempat pengambilan risiko bisa terjadi tekakan terhadap kelompoknya, (d) sebagai tempat untuk meletakkan kekuasaan. Dalam melaksanakan tugasnya hendaknya seorang pimpinan dapat mengetahui fungsi utama seorang pemimpin dalam menegakkan aturan yang harus dilaksanakan dalam menjalankan kepemimpinan.

Berdasarkan penjelasan latar belakang maka artikel ini difokuskan pada aktivitas Perilaku kepemimpinan kepala sekolah dalam mengarahkan dan mengkoordinasikan untuk mewujudkan visi dan misi di SMA Negeri 1 Lemito. Tujuan yang diharapkan dalam penelitian ini adalah mendeskripsikan perilaku kepemimpinan kepala sekolah dalam mengarahkan dan mengkoordinasikan untuk mewujudkan visi dan misi di SMA Negeri 1 Lemito.

Perilaku kepemimpinan dalam organisasi akan tercermin dari munculkan berbagai macam teori atau pendekatan. Salah satu cara yang lebih menekankan karaktersitik kepemimpinan adalah menggolongkan teori dan riset kepemimpinan berdasarkan jenis variabel yang paling diutamakan. Ada tiga jenis variabel yang relevan untuk memahami efektivitas kepemimpinan, yakni

karakteristik pemimpin, (2) karakteristik pengikut, dan karakteristik situasi (Yulk, 2001:12).

Oleh karena itu, akan bermanfaat jika menggolongkan teori ke dalam pendekatan. Pengertian dan teori kepemimpinan telah banyak diungkapkan oleh para pakar untuk mencapai tujuan organisasi yang efektif dan efisien, karena sebuah organisasi erat hubungannya dengan kepemimpinan. Kepemimpinan dapat menentukan berhasil atau tidak, maju atau mundurnya suatu organisasi. Oleh karena itu, tanggung jawab pemimpin sangat penting dalam suatu organasasi. Kualitas pemimpin sangat menentukan kemajuan suatu organisasi.

Amirullah dan Budiyono (2004:245) kepemimpinan merupakan orang yang memiliki kewenangan untuk memberi tugas, mempunyai kemampuan untuk membujuk atau mempengaruhi orang lain (bawahan) melalui pola hubungan yang baik guna mencapai tujuan yang telah ditentukan.

Berdasarkan definisi di atas dapat dijelaskan untuk mempengaruhi orang lain hendaknya seorang pemimpin harus memiliki kualitas dan kemampuan. Dengan demikian seorang pemimpin mampu menciptakan sikap loyalitas bawahannya. Seorang pemimpin hendaknya mampu mengedukasi berbagai ilmu pengetahuan pada bawahannya. Seorang pemimpin mampu memberikan solusi dan pemecahan masalah terhadap berbagai masalah yang dihadapi bawahannya serta dapat menjadi suri teladan bagi bawahannya.

Perilaku pemimpin dapat dibedakan ke dalam dua jenis perilaku, yakni pemimpin yang member-oriented dengan yang taskoriented. Seorang pemimpin yang memberoriented menitikberatkan kepemimpinannya pada usaha-usaha memotivasi kelompok untuk menerima apa yang telah digariskan sebagai tujuan kelompok dan memotivasi 
mereka guna bekerja untuk mencapai tujuan. Pemimpin seperti ini memandang penting adanya keselarasan antara anggota kelompok, disertai rasa puas pada diri masing-masing anggota tersebut. Berbeda dengan pemimpin yang member-oriented, pemimpin yang taskoriented menitikberatkan pada cara dan sarana pencapaian tujuan tertentu; ia juga selalu akan berusaha keras mengkoordinasikan sebaik mungkin para anggota kelompok.

\section{METODE PENELITIAN}

Metode yang digunakan adalah deskriptif kualitatif. Penelitian ini dilaksankan di Provinsi Gorontalo yang difokuskan di Kabupaten Pohuwato pada Kepala Sekolah SMA untuk kepala sekolah yang difokuskan pada aktivitas perilaku kepemimpinan kepala sekolah dalam mengarahkan dan mengkoordinasikan untuk mewujudkan visi dan misi di SMA Negeri 1 Lemito. Kepemimpinan dalam organisasi akan berhasil atau gagal sangat ditentukan oleh kualitas kepemimpinan. Kepemimpinan berperan penting dalam aspek manajerial dalam kehidupan berorganisasi. Seorang pemimpin berperan penting dalam menjalankan kerja sama antar kelompok dalam organisasinya. Seorang pemimpin harus mampu membedakan karakteristik organisasi yang satu dengan organisasi lainnya.

Pengumpulan data dilakukan dengan Teknik pengamatan, wawancara mendalam, dan studi dokumen. Setelah data terkumpul, kemudian dilakukan klasifikasi dan ketegorisasi sesuai dengan permasalahan yang dikaji. Hasil analisis disajikan dengan katakata/narasi secara sistematis dan ilmiah.

\section{HASIL DAN PEMBAHASAN}

\section{Hasil Penelitian}

a. Visi SMA Negeri 1 Lemito dalam Pengembangan Kebijakan Sekolah yang Berprestasi Berwawasan Iptek dan Lingkungan
Pengembangan kebijakan sekolah berprestasi berwawasan iptek dan lingkungan di SMA Negeri 1 Lemito dilaksanakan melalui beberapa indikator, yakni visi dan misi sekolah yang berprestasi yang berwawasan iptek dan lingkungan: (1) kebijakan sekolah dalam melaksanakan pengembangan pembelajaran yang efektif dan profesional, (2) kebijakan peningkatan prestasi akademik lulusan, (3) kebijakan sekolah dalam upaya tersedianya sarana prasarana pendidik yang memadai dan beraktivitas, (4) kebijakan sekolah untuk tersedianya tenaga kependidikan yang profesional, (5) kebijakan sekolah melaksanakan kegiatan peningkatan iman dan takwa, dan (6) kebijakan sekolah meningkatkan pendidikan berwawasan iptek dan Lingkungan.

Berdasarkan pengamatan di lokasi bahwa visi dan misi yang ditetapkan oleh SMA Negeri 1 Lemito terkait dengan pengembangan pendidikan berwawan iptek dan lingkungan dalam pembelajaran. Kebijakan sekolah telah dikeluarkan baik secara lisan maupun tulisan dan telah disampaikan kepada warga sekolah dan dibuktikan dengan dokumentasi.

Pada setiap organisasi, kepemimpinan adalah salah satu faktor penting. Hal ini mengisyaratkan bahwa dalam mengelola sebuah organisasi hendaknya ditentukan oleh faktor kepemimpinan.

Dari hasil wawancara diperoleh informasi terkait dengan perencanaan pengembangan kebijakan sekolah peserta didik berprestasi yang berwawasan iptek dan lingkungan di SMA Negeri 1 Lemito.

\section{b. Perilaku Kepemimpinan Kepala Sekolah dalam Menangani Konflik Formal dan Informal}

Kebijakan kepala sekolah dalam menangani konflik tidak formal dilakukan dengan memberi arahan guna meningkatkan program sekolah melalui aspek pembelajaran yang dituangkan dalam bentuk kurikulum 
berbasis lingkungan beriman dan bertakwa di SMA Negeri 1 Lemito.

Keberhasilan seorang kepala sekolah di dalam mengelola segala sumber yang ada di sekolah sangat menentukan suatu sekolah yang berkualitas dalam proses pendidikan. Guru dan tenaga kependidikan lainnya merupakan sumber daya manusia yang dapat menghasilkan output berkualitas. Semua pengelola SDM tersebut erat hubungannya dengan kepemimpinan seorang kepala sekolah.

Dalam menjalankan fungsi-fungsinya, seorang pemimpin hendaknya memiliki kecerdasan, mampu bersikap dewasa terutama di dalam menjalin hubungan sosial, berprestasi dan selalu bisa menjaga sikap. Namun demikian, temuan terkait dengan perilaku kepemimpinan kepala sekolah yang bersahaja cenderung kurang konsisten dalam menyelesaikan konflik, sebab ia lebih mengutamakan pada akademik warga sekolah sehingga menyebabkan terjadinya kompetisi yang kurang sehat dalam pembelajaran.

\section{c. Perilaku dalam Proses Pendelegasian Kewenangan}

Kebijakan kepala sekolah dalam proses pendelegasian tugas terkadang kurang formal dilakukan. Namun kepala sekolah hanya memberi secara lisan kepada bawahan. Namun kepala sekolah secara tersirat sering menyampaikan melalui arahan bersama.

Sebenarnya kepala sekolah masih kurang menggunakan kewenangan secara terbuka. Biasanya kewenangan itu diberikan kepada bawahan seperti wakil kepala sekolah atau atau guru ditunjuk untuk mengikuti tugas dan kegiatan yang tidak bisa diikutinya.

\section{Pembahasan}

Dari hasil penelitian di atas, maka dikemukakan bahwa proses perilaku kepemimpinan Kepala Sekolah SMA Negeri 1 Lemito Kabupaten Pohuwato telah menerapkan beberapa perilaku kepemimpinan yang efektif dan efisien terpadu dan terintegrasi dalam tugas warga sekolah terutama adalah membuat program dan kebijakan sekolah yang selaras dengan proses perilaku kepemipinan kepala sekolah, serta perilaku kepemimpinan kepala sekolah dalam mengarahkan dan mengkoordinasikan untuk mewujudkan visi dan misi di SMA Negeri 1 Lemito.

Pengelolan perilaku kepemimpinan di sekolah secara baik akan membentuk lingkungan sekolah yang lebih berkwalitas dan profesional sebagaimana menjadi visi SMA Negeri 1 Lemito, terutama menjaga keharmonisan warga sekolah, sebaliknya pengelolaan kempemimpnan yang baik dan sehat akan sangat mendukung proses belajar mengajar yang dilaksanakan di sekolah, hasil mutu dan prestasi sekolah meningkat.

Kebijakan pimpinan dalam visi dan misi dapat dilihat proses perilaku kepemimpinan Kepala SMA Negeri 1 Lemito Kabupaten Pohuwato. Temuan dari komponen ini difokuskan pada visi dan misi, kebijakan Kepala Sekolah SMA Negeri 1 Lemito Kabupaten Pohuwato dalam mendukung proses perilaku kepemimpinannya yaitu:

Pertama, visi misi SMA Negeri 1 Lemito merupakan hasil rancangan yang dibuat berdasarkan hasil kesepakatan seluruh warga sekolah. Hal ini disesuaikan dengan keadaaan wilayah dan budaya setempat serta dikembangkan berdasarkan kurikulum yang ada.

Visi SMA Negeri 1 Lemito adalah "Menuju peserta didik berprestasi yang berwawasan iptek dan lingkungan dengan dilandasi iman dan takwa”. Berdasarkan bunyi visi tersebut nampak bahwa pendidikan yang dilaksanakan didasarkan pelayanan iptek, seni dan imtak yang berwawasan lingkungan. Pembelajaran yang dilaksanakan di sekolah merupakan penjabaran dari visi yang ditetapkan, di mana dalam proses pembelajaran memanfaatkan lingkungan.

SMA Negeri 1 Lemito, misi tersebut merupakan penjabaran dari visi yang dirumuskan. Makna yang terkandung dalam misi pertama adalah memberdayakan dan 
mengembangkan seluruh potensi iptek dan lingkungan sekolah dalam pendidikan. Hal ini berarti seluruh warga sekolah, baik kepala sekolah, guru, pegawai tata usaha, peserta didik dan masyarakat dituntut berperan aktif dalam pengembangan potensi lingkungan sekolah dalam proses pendidikan, terutama dalam pembelajaran di dalam kelas maupun di luar kelas.

Makna yang terkandung pada misi kedua adalah sekolah diusahakan menjadi sekolah yang berwawasan lingkungan, artinya sekolah menjadi salah satu pusat pembelajaran dan pemberdayaan warga sekolah untuk menjaga dan memelihara lingkungan warga sekolah. Sehingga dapat dicontohi oleh mayarakat sekitar dan sekolahsekolah lainnya.

Menurut Wibisono (2006), visi merupakan rangkaian kalimat yang menyatakan cita-cita atau impian sebuah organsasi atau perusahaan yang ingin dicapai di masa depan. Atau dapat dikatakan bahwa visi merupakan pernyataan want to be dari organisasi atau perusahaan. Visi juga merupakan hal yang sangat krusial bagi perusahaan untuk menjamin kelsetarian dan kesuksesan jangka panjang.

Kedua, kebijakan yang telah dijabarkan oleh kepala sekolah melalui visi misi, dapat menggambarkan keberhasilan seorang pemimpin dalam menekan konflik internal sekolah di samping penentuan proses perilaku pemimpin dipengaruhi oleh sifatsifat, perangai atau ciri-ciri yang dimiliki oleh pemimpin. Dengan demikian efektifitas kepemimpinan sangat dipengaruhi oleh karakteristik seorang pemimpin.

Ketiga, kebijakan peningkatan kapasitas SDM merupakan salah satu kebijakan yang dilaksanakan oleh kepala sekolah dalam memberdayakan warga sekolah untuk lebih fokus pada peningkatkan prestasi siswa. Untuk meningkatkan SDM di sekolah maka sekolah perlu mengadakan workshop, pelatihan bagi siswa dan guru. Peningkatan sumber daya guru dapat dilaksanakan pada setiap awal semester.
Dengan demikian kepala sekolah memerlukan konseptual pola kempemimpinan yang ideal, sehingga seyogianya Kepala Sekolah SMA Negeri 1 Lemito tampil sebagai pemimpin yang dapat memberi pengaruh, mengarahkan dan memotivasi para bawahan, sehingga mereka mau mengikuti dan melakukan apa yang diharapkan atau diingatkan oleh pemimpin sesuai dengan visi, misi dan tuuan organisasi. Kajian skematis dari indikator kebijakan sekolah dalam proses perilaku dapat digambarkan sebagai berikut.

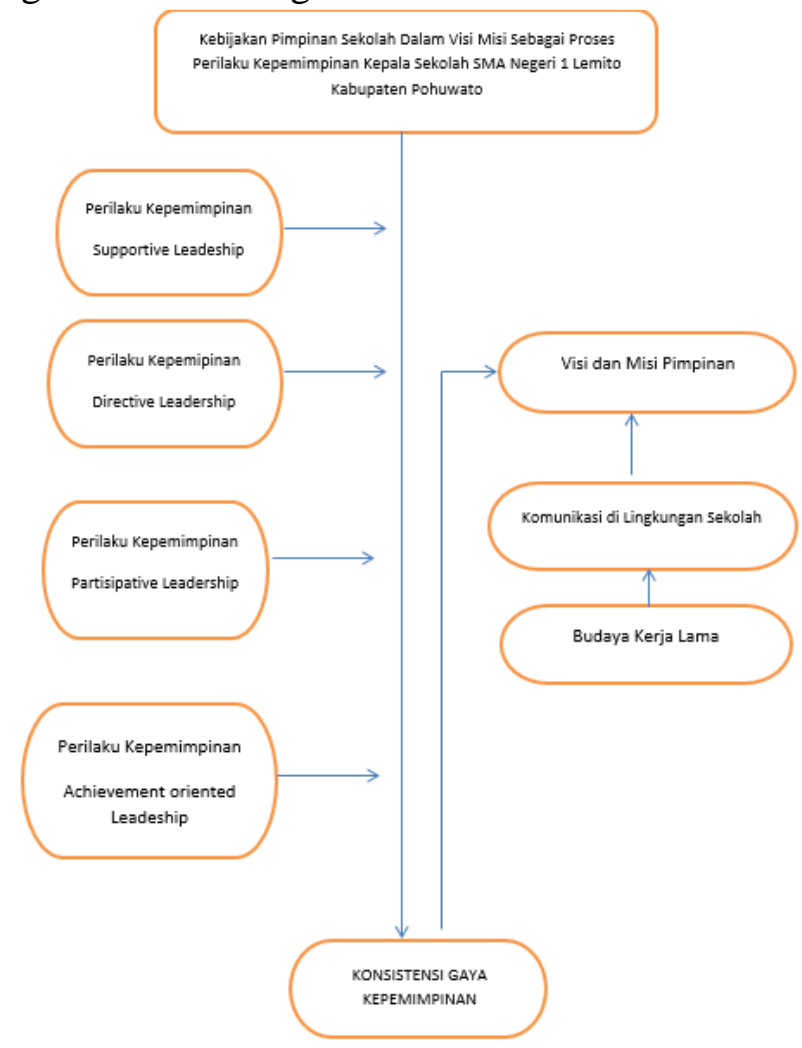

Skema di atas menggambarkan bahwa secara realitas kepala sekolah sebagai pimpinan di SMA Negeri 1 Lemito melakukan beberapa kebijakan pengembangan sekolah dengan mengedapankan visi dan misi sekolah tujuan bersama. Dengan tingkat kompleksitas permasalahan yang begitu rumit kepala sekolah melakukan beberapa pendekatan perilaku kepemimpinan pada warga sekolah dengan melihat kondisi dan realitas di 


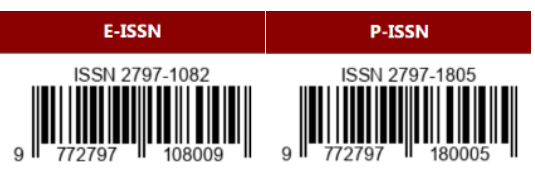

Volume 2 Nomor 1 (Desember 2021 - Februari 2022)

sekolah. Perilaku yang menonjol yang dilakukan oleh kepala sekolah dalam hal ini adalah lebih mengendepankan pencapaian hasil target sesuai visi misi, sebab kepala sekolah sangat yakin dengan proses perilaku berorientasi pada hasil ini masing-masing individu warga sekolah akan melupakan perbedaan pendapat dan persaingan internal di sekolah karena tujuan utama adalah meningkatkan prestasi sekolah.

Pada saat tertentu kepala sekolah melakukan pendekatan perilaku yang mendukung hasil kerja warga sekolah baik secara individu maupun kelompok. Namun, pimpinan menyadari proses perilaku ini membutuhkan kesabaran yang tinggi terutama harus menghadapi kebiasaan atau budaya lama di sekolah. Dengan berbagai pendekatan yang telah dilakukan oleh kepala sekolah ini prestasi sekolah di tingkat Kabupaten Pohuwato SMA Negeri 1 Lemito mampu melahirkan prestasi yang menggembirakan seperti juara 1 atletik tingkat kabupaten selama 3 tahun berturut-turut, bahkan mengirimkan siswa dan guru pendamping mengikuti kegiatan di tingkat nasional baik di bidang olah raga maupun di bidang kemampuan mata pelajaran melalui lomba OSN di Palembang. Sementara itu, kepala sekolah melakukan beberapa terobosan dengan member peluang kepada para guruguru untuk meningkatkan kompetensi pengetahuan maupun pendidikan seperti mengikuti seminar, pelatihan dan pendidikan lanjut.

\section{KESIMPULAN DAN SARAN Kesimpulan}

Berdasarkan temuan penelitian terkait dengan perilaku kepemimpinan kepala Sekolah SMA Negeri 1 Lemito sebagai berikut.

1. Proses perilaku kepemimpian kepala sekolah telah menerapkan beberapa perilaku kepemimpinan yang efektif dan efisien. Dalam kebijakan perilaku kepemimpinan lebih dominan dipengaruhi oleh pencapaian visi dan misi sekolah, lingkungan sekolah, dan budaya kerja.

2. Pengelolaan perilaku kepemimpinan di sekolah dalam menyelaraskan tujuan individu dan kelompok dilakukan secara terbuka dengan tidak menciptakan perbedaan persepsi antarwarga sekolah.

3. Kebijakan yang tidak dijabarkan oleh kepala sekolah melalui visi dan misi dapat menggambarkan keberhasilan seorang pemimpin dalam menekan konflik internal sekolah di samping penentuan proses perilaku pemimpin.

4. Perilaku pemimpin mendelegasikan tugasnya masih dipegaruhi oleh keraguan pada tingkat kepercayaan warga sekolah, kemampuan dan skil serta masih rendahnya prestasi kerja warga sekolah.

\section{Saran}

Berdasarkan penelitian di atas maka disarankan sebagai berikut.

1. Kepala sekolah dapat melaksanakan aktivitas perilaku kepemimpinan kepala sekolah dalam mengarahkan dan mengkoordinasikan untuk mewujudkan visi dan misi di SMA Negeri 1 Lemito.

2. Kepala sekolah sebaiknya membuka pola kepemimpinan yang lebih dnegan warga sekolah, sehingga untuk menyukseskan program sekolah dapat dilaksanakan secara sepenuhnya

3. Dalam pelaksanaan program sebaiknya kepala sekolah memanfaatkan fasilitas yang ada dan seluruh potensi sekolah dengan mengelola beberapa perbedaan pendapat menjadi solusi penyelenggaraan program visi dan misi sekolah terutama dalam mengeliminir konflik internal warga sekolah

4. Kepada peneliti yang relevan bahwa yang dapat dijadikan variabel lainnya dalam penelitian lanjutan adalah dari segi gaya kepemimpinan kepala sekolah, budaya dan pola komunikasi organisasi. 


\section{DAFTAR PUSTAKA}

Ardianto, A., Gonibala, R., Hadirman, H., \& Lundeto, A. (2020). NILAI PENDIDIKAN KARAKTER BANGSA DALAM TRADISI KATOBA PADA MASYARAKAT ETNIS MUNA. Potret Pemikiran, 24(2), 86-107.

Bolotio, R., Hadirman, H., \& Musafar, M. (2021). Prolematika Pengelolaan Pendidikan Islam Non-Formal Pada Komunitas Muslim. Jurnal Ilmiah Iqra', 15(1), 32-47.

Amirullah, dan Haris, Budiyono. (2004). Pengantar Manajemen. Yogyakarta: Graha Ilmu.

Amstrong, Michael. (1998) Seri Manajemen Sumber Daya Manusia Penerjemah Sofyan Cikmat dan Haryanto. Jakarta: PT. Alex Media Komputindo.

Burhanudin. (2007). Analisis Administrasi Manajemen dan Kepemimpinan Pendidikan. Jakarta: Bumi Aksara.

Hasibuan, Malayu S.P. (2007). Manajemen Sumber Daya Manusia. Cetakan kesembilan. Jakarta: PT Bumi Aksara.

Luma, M., Tola, A., \& Hadirman, H. (2020). Evaluasi Implementasi K-13 Berdasarkan Model CIPP di SDN 2 Tabongo Kabupaten Gorontalo. Jurnal Ilmiah Iqra', 14(2), 186-204.

Mangkunagara, Anwar Prabu. (2005). Manajemen Sumber Daya Manusia Perusahaan. Bandung: PT Remaja Rosdakarya

Sanjaya, Wina. (2013). Penelitian Pendidikan: Jenis, Metode dan Prosedur. Jakarta: Prenada Media Group.

Sugiyono. (2008). Metode Penelitian pendidikan pendekatan Kualitatif, Kuantitatif dan $R \& D$. Bandung: Alfabeta.

Wahjosumidjo. (1994). Kepemimpinan dan Motivasi. Jakarta: Ghalia Indonesia.
Wahyudi. (2008). Manajemen Konflik Dalam Organisasi. Bandung: Alafabeta.

Woodworth. (2001). Bimbingan dan Penyuluhan di Sekolah. Yogyakarta: Andi Offset.

Yamin, Martinis. (2006). Profesionalisasi Guru dan Implementasi KTSP. Jakarta: Gaung Persada Press.

Yulk, Gary A. (2001). Kepemimpinan dalam Organisasi. Edisi kelima Terjemahan. Jakarta: PT. Indeks. 